\title{
Altitudinal gradient of mass-balance sensitivity to climatic change from 18 years of observations on glacier d'Argentière, France
}

\author{
M. Vallon, C. Vincent, L. Reynaud \\ Laboratoire de Glaciologie et Géophysique de l'Environnement du CNRS, and Université Joseph Fourier, \\ 38402 Saint-Martin-d'Hères Cedex, France
}

\begin{abstract}
Assessment of the contribution of small glaciers to sea-level rise or the reconstruction of past glacial mass balance requires knowledge of mass-balance sensitivity to climatic variations. The aim of this paper is to clarify this relation. The massbalance fluctuations analyzed from measurements on glacier d'Argentière, Mont Blanc massif, France, between 1850 and $2700 \mathrm{~m}$ a.s.l. were compared with climatic variations at a nearby meteorological station. Statistical study of the data shows that: (1) the annual mass-balance fluctuations are dependent on elevation, and (2) the mass-balance sensitivity to temperature decreases with altitude and diverges from current model results. Consequences of a temperature variation of $1{ }^{\circ} \mathrm{C}$ for global volume variations are significant. A simple calculation on glacier des Bossons, Mont Blanc massif, France, shows that the sensitivity from the model can lead to volume variations twice as high as results compatible with our observations.
\end{abstract}

\section{INTRODUCTION}

Ever since Meier (1984) pointed out the potentially large contribution of small glaciers (excluding the large polar ice sheets, Greenland and Antarctica) to sea-level fluctuations, all proposed climatic-change scenarios have included estimates of the consequences of an increase in the mean temperature of the troposphere for the volume of mountain glaciers. Since 1984, mass-balance sensitivity to temperature fluctuations has been largely reconsidered Warrick and Oerlemans, 1990; Oerlemans and Fortuin, 1992; Trupin and others, 1992): the suggested contribution of small glaciers to sea level decreased between 1984 (estimation by Meier) and 1992 (estimation by Oerlemans), from 1.30 to $0.58 \mathrm{~mm}$ year ${ }^{-1} \mathrm{C}^{-1}$ (Meier, 1993).

Two methods can be used to obtain such an estimate. For the first method, as described by Martin (1975), an empirical relationship is established between the climatic variability and the mass-balance fluctuations. In the second, as described by Oerlemans (1993), the glacier mass-balance variations are estimated by analyzing the probable changes in the various terms of the energy balance. The two methods appear to give similar results. The temperature sensitivity of mountain glaciers, at least for the Alps and Scandinavia, the regions most studied to date, would appear to be about -0.4 to $-0.6 \mathrm{~m}$ ice ${ }^{\circ} \mathrm{C}^{-1}$ (Kuhn, 1981; Letréguilly, 1984; Chen and Funk, 1990; Oerlemans, 1993). From these results, it is tempting to generalise these relationships on a large spatial scale to estimate global ice-melting volume for $1^{\circ}$ or $2^{\circ} \mathrm{C}$ temperature elevation in the future.

Nevertheless, such operations have limits; in this paper, we analyze the mass-balance sensitivity to climatic fluctuations depending on elevation. If it is assumed that temperatures and precipitation gradients are linear, empirical relationships between the specific balance of the glacier and climatic fluctuations, of the form $b_{\mathrm{s}}=\alpha \mathrm{d} T+\beta \mathrm{d} P$, where $b_{\mathrm{s}}$ is the specific balance, $\mathrm{d} T$ is a temperature variation, $\mathrm{d} P$ is a precipitation variation and $\alpha$ and $\beta$ are coefficients to be determined, are valid only within the context of the linear model proposed by Lliboutry (1974); according to this approach, mass-balance fluctuations are independent of elevation.

But such a model is valid only over an area similar in size to the area for which it was developed, i.e. for glaciers of not more than a few $\mathrm{km}^{2}$. Kuhn (1984) suggested that a non-linear approach could, conceptually speaking, be equally useful. Indeed, it is unreasonable to assume that a summer temperature variation of $1{ }^{\circ} \mathrm{C}$ or a winter precipitation variation of $10 \mathrm{~cm}$ of water at Chamonix would result in the same mass-balance variation at an elevation of $1200 \mathrm{~m}$ near the bottom of glacier des Bossons and at the $4800 \mathrm{~m}$ high summit of Mont Blanc.

The response of glacier mass balance to climatic change should, in principle, be very strongly dependent on elevation. At high elevation, in regions where turbulent exchange plays a negligible role, air-temperature variations have a much smaller effect. Inversely, in mountain regions, given the increase in precipitation with elevation, the effect of precipitation fluctuations should increase with elevation. Instead of the sensitivity of the specific balance to climatic fluctuations, therefore, we will consider the sensitivity of the mass-balance-elevation relationship to these fluctuations.

\section{SENSITIVITY OF MASS BALANGE TO CLIMATIC FLUCTUATIONS}

In an attempt to describe this relationship in detail, we have 
used a series of measurements made on glacier d'Argentière, Mont Blanc massif, France, by the Laboratoire de Glaciologie et Géophysique de l'Environnement du Centre National de la Recherche Scientifique, extending back to 1975. On this glacier, the mass balances have been measured regularly at four different elevations between 1850 and $2700 \mathrm{~m}$. The Chamonix meteorological station, at an elevation of $1000 \mathrm{~m}$, is located just a few kilometres from the glacier.

The observation period (18 years) may appear to be somewhat short. However, studying the stability of the relationship between the specific balance and climate for glacier de Sarennes, Gelbert (1986) found that, although periods of 5-10 years are insufficient to establish a reliable relationship, statistical analysis of data covering a period of more than 15 years gives unchanging explanatory variables and stable regression coefficients.

Each observation site (1850, 2400, 2550 and $2700 \mathrm{~m}$ a.s.l.) is a zone of about $0.25 \mathrm{~km}^{2}$ on which mass balances are measured at three to ten stakes.

Because of the exposition, slope and debris or snow on the glacier surface, spatial variability is very significant at 1850 and $2700 \mathrm{~m}$ (in these regions mass-balance gradients are of 1-2 $\mathrm{m}$ ice year ${ }^{-1}$ per $100 \mathrm{~m}$ horizontal distance in the vicinity of the stakes).

Sites of ablation stakes are not strictly the same from year-to-year, and the mean value of the observed mass balance in each zone alone already has a large "noise". To reduce uncertainty about the characteristic mass balance for each zone, the statistical method used by Lliboutry (1974) for the analysis of St Sorlin mass balance (linear model with incomplete table of balance values) was applied for each zone.

In such a linear model, mean mass-balance uncertainty can be reduced to about $0.5 \mathrm{~m}_{\text {water year }}^{-1}(\sigma=0.3-0.6 \mathrm{~m}$, depending on zone and time), although the standard error of the mean mass balance can exceed 1.50 m water year $^{-1}$ when calculated by arithmetic mean.

From all the observations, it is possible to calculate characteristic annual mass balance for each zone (Fig. 1).

The main results of the statistical analysis of 18 years of observations are as follows:

(1) The linear model of mass-balance variations is not applicable; the inter-annual variability of the mass balance decreases regularly with elevation $(4 \sigma=5.08 \mathrm{~m}$ of water at $1850 \mathrm{~m}, 3.76 \mathrm{~m}$ of water at $2375 \mathrm{~m}$, and $2.88 \mathrm{~m}$ of water at $2725 \mathrm{~m}$ ).

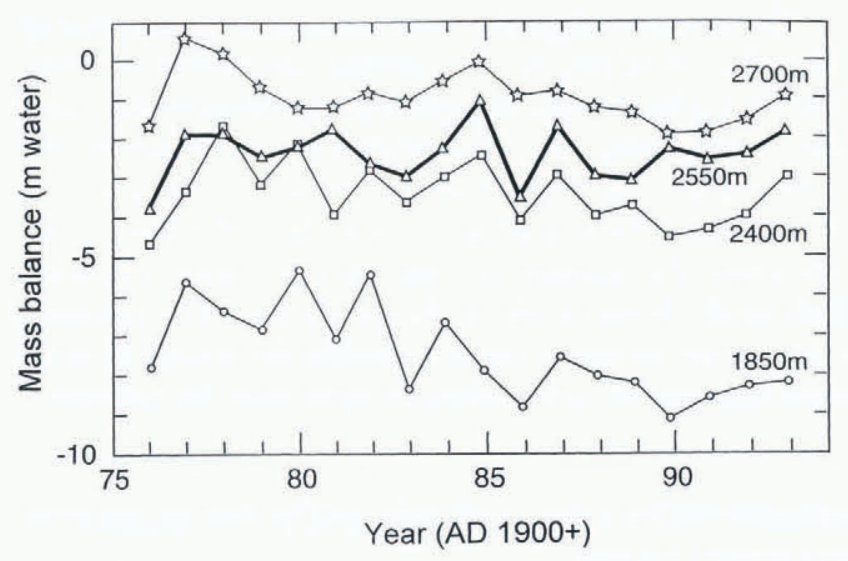

Fig. 1. Glacier d'Argentière characteristic mass balance for different zones in respect to time (1975-93).
(2) The mass-balance fluctuations are nonetheless highly correlated, with $81 \%$ of the variance being in common, probably of climatic origin, and only $12 \%$ corresponding to differences in elevation (it is this very high covariance that gives the impression that the linear model is a good approximation, given the relatively large noise affecting the mass-balance measurements).

(3) The only pertinent explanatory variables are: (a) the temperature during the ablation season (May-August), accounting for $25-50 \%$ of the variance, depending on the zone, and (b) the winter precipitation (OctoberMay), hardly significant at the $5 \%$ threshold, responsible for $10-15 \%$ of the variance.

Figure 2 shows the values of the regression coefficients for the relationship between the mass-balance and temperature variations. The values obtained $(0.42-1.08 \mathrm{~m}$ water ${ }^{\circ} \mathrm{C}^{-1}$ ) are comparable to the sensitivities observed by other investigators both for the Alps and for Scandinavia. In spite of the high uncertainty associated with these values, we can affirm that the sensitivity actually decreases with elevation. For the sake of comparison, we have plotted two curves showing the mass-balance sensitivity to temperature variations. One of the curves is deduced from the simulation made by Oerlemans (1993) using his model. The other is derived from the empirical relationship proposed by Krenke and Khodakov (1966), between ice ablation and mean temperature during the ablation season. The model used by Oerlemans appears to overestimate greatly the sensitivity of low-elevation mass balances to temperature variations.

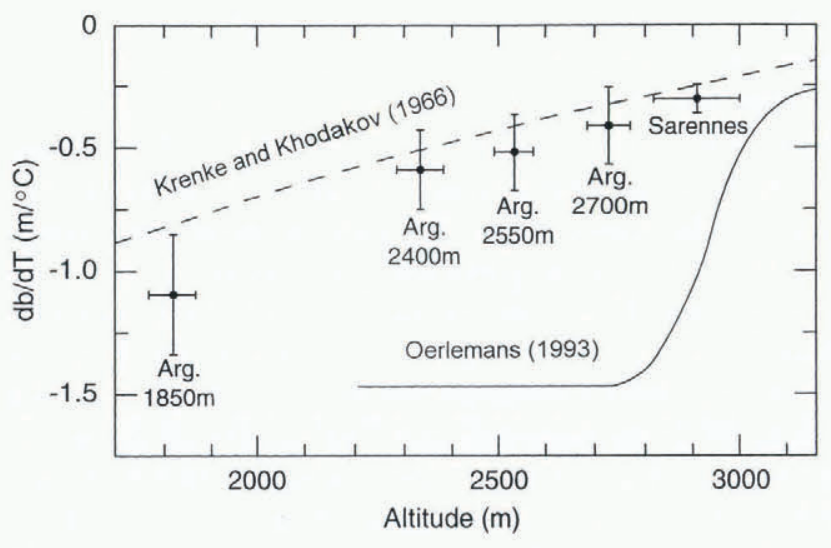

Fig. 2. Mass-balance-temperature relation observed on glacier d'Argentière. Comparison with Krenke and Khodakov's (1966) empirical relation and Oerlemans' (1993) model $\left(1 \mathrm{hm}^{3}=10^{6} \mathrm{~m}^{3}\right)$. The calculations, with the empirical relation of Krenke and Khodakor, i.e. ablation (mm of water) $=\left(\text { mean summer temperature }\left({ }^{\circ} \mathrm{C}\right)+10\right)^{3}$, are performed using the mean summer (June-August) temperature in Chamonix and a lapse rate of $7^{\circ} \mathrm{Ckm}^{-1}$.

Oerlemans' model, in which a complex albedo parameterisation (nine parameters) is able to explain $75 \%$ of energy exchange and $85 \%$ of mass-balance variation with altitude in the ablation zone, is not adapted to explain interannual mass-balance fluctuations. In this model, the shift of the equilibrium line due to temperature change leads to a surface albedo variation on the whole glacier, and this surface albedo decreases drastically down-glacier below the equilibrium line. But the surface appearance of the ablation zone, after melting of the winter snow (rock debris, dust 
wells, petrographic characteristics of ice) does not change each year with altitude fluctuations of the equilibrium line. Therefore, it would be surprising if this model fitted well with observations.

On the other hand, the empirical relationship proposed by Krenke and Khodakov provides a very satisfactory fit for the observations of glacier d'Argentière as well as those of glacier des Sarennes, $100 \mathrm{~km}$ to the south. This relationship is influenced by ablation values obtained from regions where there is a large turbulent energy flux (Khodakov, 1975). In the French Alps, the contribution of radiation to ablation decreases strongly with altitude $43 \%$ of exchange at $2700 \mathrm{~m}$ a.s.l., according to Martin, 1975, and 5\% of exchange at $3600 \mathrm{~m}$ a.s.l., according to De la Casinière, 1971).

Besides, it can be noticed that the mass-balance sensitivity to temperature equal to $0.5 \mathrm{~m}$ water ${ }^{\circ} \mathrm{C}^{-1}$ proposed by many authors is linked to observations made on a limited zone of glaciers (ablation zone).

The implications of these results for the relationship between mass balance and temperature can be seen in Figures 3 and 4, in which we have plotted, for glacier des Bossons (a large glacier in the Mont Blanc range), from the summit of Mont Blanc to the snout of the glacier, and for glacier d'Argentière, the total volume variation. This would result in a temperature variation of $1^{\circ} \mathrm{C}$ on the basis of three different models, i.e. the linear model with a coefficient of $0.5 \mathrm{~m}_{\text {water }}{ }^{\circ} \mathrm{C}^{-1}$, the model proposed by Oerlemans (1993) and the relationship proposed by Krenke and Khodakov (similar to the relationship observed on glacier d'Argentière).

For glacier d'Argentière (Fig. 4), results are strongly influenced by the geometry of the accumulation zone: the glacier is surrounded by very steep non-glacial slopes, which are responsible for most of the accumulation. Therefore, the glacial accumulation zone is small and reduces drastically

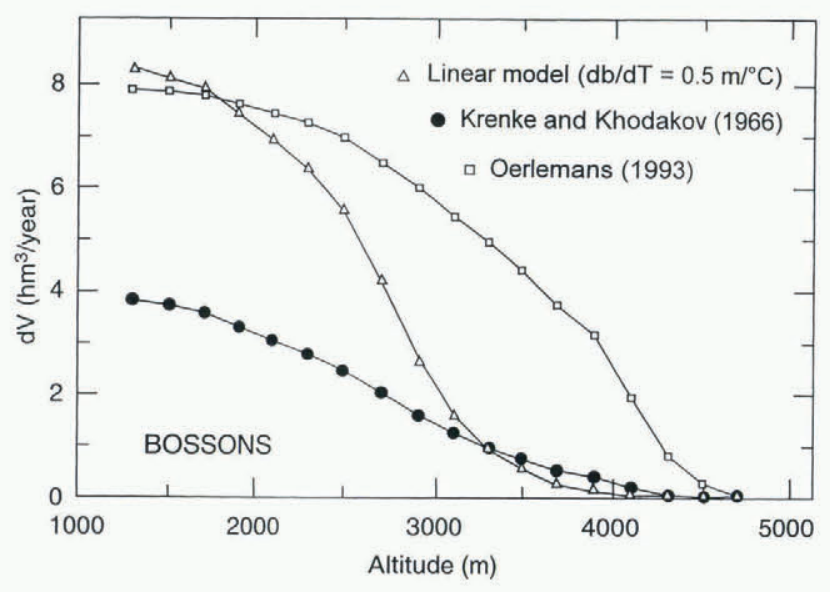

Fig. 3. Cumulated volume variation for glacier des Bossons resulting in a temperature variation of $1^{\circ} \mathrm{C}$, for three different models $\left(1 \mathrm{hm}^{3}=10^{6} \mathrm{~m}^{3}\right)$. The linear model predicts unrealistic variations of volume in the accumulation zone; both the linear and Oerlemans models predict much more significant variations in the flux of ice near the snout than observed. For the $1^{\circ} \mathrm{C}$ variation of temperature in the Northern Hemisphere observed between 1890 and 1990 (Hansen and Lebedeff, 1988), the snout of glacier des Bossons would move about $2.6 \mathrm{~km}$ with the linear and Oerlemans models, $1.3 \mathrm{~km}$ with the Krenke and Khodakov relation. The observed fluctuation of the front is only $1.0 \mathrm{~km}$ between the maximum advance of 1890 and the retreat of 1995.

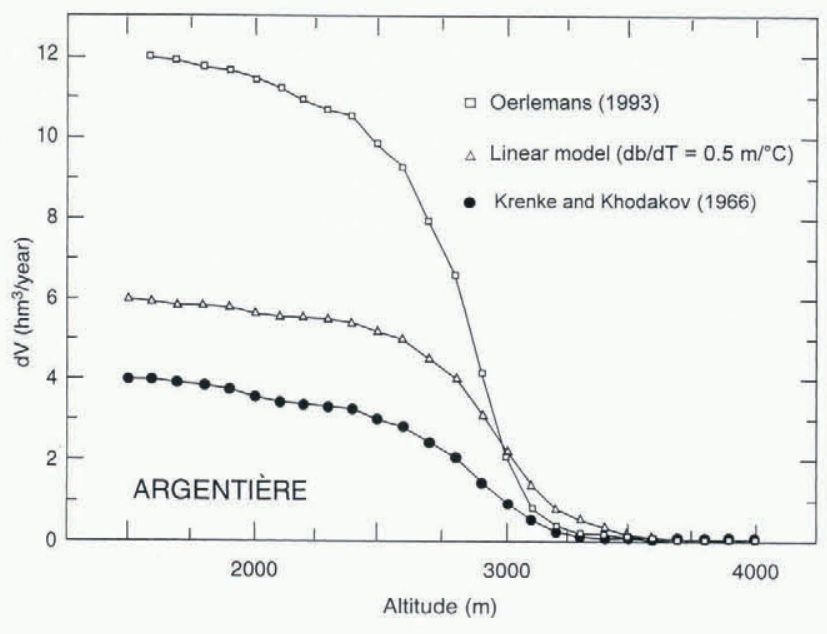

Fig. 4. Cumulated volume variation for glacier d'Argentière resulting in a temperature variation of $1^{\circ} \mathrm{C}$ for three different models.

the cumulated volume variation calculated in the linear model. (The other models are not much affected, because the sensitivity is very low above the equilibrium line.) From this point of view, glacier des Bossons is more representative than other glaciers.

Thus, from glacier des Bossons results, we can say that the models generally used to estimate ocean-volume, variations produce estimates for glacier-volume variations that are twice those calculated using a relationship corresponding to the observations made on glacier d'Argentière.

Concerning precipitation fluctuations, the sensitivity of glacier mass balance to this parameter is more difficult to estimate reliably than its sensitivity to temperature fluctuations. The inter-annual precipitation fluctuations are generally of the same order of magnitude as the uncertainty in mass-balance measurements $( \pm 0.2$ to $\pm 0.3 \mathrm{~m}$ of water). With a relationship of the form $b=\beta \mathrm{d} P$, where $\beta$ would appear to be on the order of $2 \pm 1$ in the Alps and in Scandinavia, the statistical estimation of $\beta$, subject to the uncertainty both in the mass-balance measurements and in the statistical relationship between mass balance and temperature, is obviously highly uncertain. To obtain a reliable relationship, it will be necessary to estimate directly the relationship between accumulation and precipitation at various elevations.

\section{CONCLUSIONS}

Although extending over an elevation range of $900 \mathrm{~m}$, our observation network on glacier d'Argentière is still too limited to assess reliably the sensitivity of mass balances to temperature fluctuations. In order to do so, it would be necessary to extend these observations both upwards, in the accumulation zone, and downwards, into the low-elevation regions near the snouts of large glaciers. According to Jóhannesson and others (1989), the ablation value at the snout is one of the key parameters affecting the extension of glaciers and their response times.

A linear model of mass-balance variations is acceptable only for a limited elevation range (a few hundred metres). In addition, the empirical relationship of Krenke and Khodakov (1966) between the mass-balance sensitivity to temperature and the elevation (Fig. 2), which has been 
obtained from observations made worldwide on a great number of glaciers, is absolutely comparable to the results obtained on glacier d'Argentière by a statistical method, whereas the results stemming from Oerlemans' model clearly diverge from our observations.

Consequences for global volume variations of glaciers for a temperature variation of $1^{\circ} \mathrm{C}$ are significant. In fact, a simple calculation on glacier des Bossons shows that a linear model of mass-balance variation or Oerlemans' model leads to volume variations twice as high as results compatible with our observations.

\section{ACKNOWLEDGEMENTS}

We would like to thank all those who collected data from glacier d'Argentière, over a long period, and especially C. Carle, D. Hantz and Y. Morin. This study was supported by the hydroelectric company Emosson (La Batiaz-Switzerland). R. J. Braithwaite corrected the English.

\section{REFERENCES}

Chen, J. and M. Funk. 1990. Mass balance of Rhonegletscher during 1882 83-1986/87. f. Glaciol., 36 (123), 199-209.

De la Casinière, A. C. 1971. Contribution à l'étude des bilans thermiques au dessus de la neige à haute et moyenne altitude. (Thèse d'Etat, Laboratoire de Glaciologic du CNRS et de l'Université Scientifique et Médicale de Grenoble.)

Gelbert, C. 1986. Essai de reconstitution des bilans de masse glaciaires dans les Alpes depuis 1526. (Mémoire de Diplôme d'Etudes Approfondies, UniversitéJoseph Fourier, Grenoble.
Hansen, J. and S. Lebedeff. 1988. Global surface air temperature: update through 1987. Geophys. Res. Lett., 15 (4), 323-326.

Jóhannesson, T., C. Raymond and E.D. Waddington. 1989. Time-scale for adjustment of glaciers to changes in mass balance. f. Glaciol., 35(121), $355-369$.

Khodakov, V. G. 1975. Glaciers as water resource indicators of the glacial areas of the USSR. International Association of Hydrological Sciences Publication 104 (Symposium at Moscow 1971 - Snow and Ice), 22- 29.

Krenke, A. N. and V. G. Khodakov. 1966. O svyazi poverkhnostnogo tayaniya lednikov s temperaturoy vozdukha [The relationship between surface ice melting and air temperature]. Mater. Glyatsiol. Issled. 12, 153-164.

Kuhn, M. 1981. Climate and glaciers. International Association of Hydrological Sciences Publication 131 (Symposium at Canberra 1979 - Sea Level, Ice and Climatic Change), 3-20.

Kuhn, M. 1984. Mass budget imbalances as criterion for a climatic classification of glaciers. Geogr. Ann., 66A (3), 229-238.

Letréguilly, A. 1984. Bilans de masse des glaciers alpins: méthode de mesure et répartition spatio-temporelle. (Thèse de 3ème cycle, Laboratoire de Glaciologie du CNRS et UniversitéJoseph Fourier, Grenoble.)

Lliboutry, L. 1974. Multivariate statistical analysis of glacier annual balances. 7. Glaciol., 13 69), 371-392.

Martin, S. 1975. Corrélation bilans de masse annuels - facteurs métérologiques dans les Grandes Rousses. Z. Gletscherkd. Glazialgeol., 10 (1-2), 1974, 89-100.

Meier, M. F. 1993. Ice, climate, and sea level: do we know what is happening? In Peltier, W.R., ed. Ice in the climate system. Berlin, etc., Springer-Verlag, 141-160. (NATO ASI Series I: Global Environmental Change 12.)

Oerlemans, J. 1993. A model for the surface balance of ice masses. Part 1. Alpine glaciers. Z. Gletscherkd. Glazialgeol., 27-28, 1991-1992, 63-83.

Oerlemans, J. and J. P. F. Fortuin. 1992. Sensitivity of glaciers and small ice caps to greenhouse warming. Science, 258(5079), 115-117.

Trupin, A. S., M. F. Meier andJ. M. Wahr. 1992. Effect of melting glaciers on the Earth's rotation and gravitational field: 1965-1984. Geophys. J. Int., $108(1), 1-15$.

Warrick, R. and J. Oerlemans. 1990. Sea level rise. In Houghton, J.T., G. J. Jenkins and J.J. Ephraums, eds. Climate change: the IPCC scientific assessment. Cambridge, etc., Cambridge University Press, 257-281.

MS received 22 January 1997 and accepted in revised form 15 October 1997 